Ethiopian Journal of Environmental Studies \& Management 10(5): 691 - 704, 2017.

ISSN:1998-0507

doi: https://dx.doi.org/10.4314/ejesm.v10i5.12

Submitted: April 18, 2017

Accepted: July 13, 2017

\title{
RATE OF LAND COVER CHANGE AND ITS DETERMINANTS IN THE SOUDANO- GUINEA TRANSITION ZONE OF BENIN REPUBLIC
}

JOSEPH OLOUKOI

African Regional Institute for Geospatial Information Science and Technology

(AFRIGIST), Off Road 1, Obafemi Awolowo University Campus, PMB 5545, Ile-Ife,

Nigeria

Email: oloukoi@ rectas.org.ng, chabijos@gmail.com

\begin{abstract}
The paper assesses land cover dynamics and its associated drivers in the soudano-guinea transition zone of Benin Republic, using both spatial and non-spatial data. Multispectral and multi temporal Landsat imageries (Landsat TM of 1986, ETM+ of 2000 and OLI-TIRS of 2013) were used for the analysis of land cover dynamics through a supervised classification. Logistic Multiple Regression model is used to analyse the relationship between the rate of land cover change and nine explanatory variables considered as potential factors of land cover change rate. Land cover change rate was estimated to an average of $-4.34 \%$ annually. This rate appears higher than the national rate estimated at $1.2 \%$ by Food and Agriculture Organization (FAO). The rate of change classified into four modalities ranging from -8.77 to -1.13 , show a gradual decrease towards the northern part of the study area. From the $R^{2}$, it is observed that the nine variables explained about $35.30 \%$ of the occurrence of land cover change. Variables such as 'rank of agriculture in the source of income' and 'accessibility' are significantly influencing the rate of land cover change in the study area. The paper further advocates for the need to dwell more on indirect factors which remotely influence environmental dynamics.
\end{abstract}

Key Words: Land cover, Rate of change, Benin, Logistic multiple regression, Determinants

\section{Introduction}

Land Use Land Cover Change (LUCC) highlights the impacts of global environmental change and human interaction with the natural systems (Karanam et al., 2013; Hibbard et al., 2010). Due to the important contributions and role of land in providing environmental goods and services for human sustainability (Showqi et al., 2014), there have been an increased interest in land use land-cover (Badjana et al., 2015; Lawrence and Chase, 2010). The change observed in Land-cover is one of the most important drivers of global change that affects the climate (Takahashi et al., 2010), the biogeochemical cycles and energy fluxes and thereby the livelihoods (Melillo et $a l ., 2003)$. The change in land cover is influenced by ecological mechanisms, physical components of the environment 
and socioeconomic interactions (Were et al., 2014; Kanianska et al., 2014; Hu et al., 2012).

There have been some studies on land cover dynamics in the climatic transition zone of Benin. For instance, RIVERTWIN project developed and implemented an Integrated Regional Model which indicated that land use/cover data are useful in environmental resources assessment and planning (European Research Area, 2004). Within the framework of this project, Igue et al. (2012) developed a Soil and Land Resources Information System in which 17 land cover classes were generated. However, the factors responsible for land cover dynamics were not considered.

Also, IMPETUS Benin project for Oueme basin investigated the relationship between spatio-temporal vegetation dynamics and hydrological cycle between 1986 and 2002. The report of the project revealed threefold causes of land cover change including agricultural colonization, logging and growth of settlements (IMPETUS West Africa, 2003). In the context of this project, Thamm et al. (2005) reported that agricultural land was extending while dense forests were reduced from $11 \%$ to $6 \%$ between 1986 and 2001. Orekan (2007) traced these changes to population growth, migration and change in climatic conditions while Do et al. (2014) used a diachronic analysis to show a loss of $87 \%$ in forested zones, $48 \%$ in savanna and $39 \%$ in cropland. However, the spatial coverage is the upper Oueme Catchment area which is not included in this study area.
Other studies have also drawn attention to land cover change in the study area. For example, Oloukoi (2013) analysed the socioeconomic and ecological scenario of land cover change in the central part of Benin. However, the study did not use statistical model to show the contribution of the drivers in land cover change.

The present paper therefore analyses the types of drivers and their contribution to land cover dynamics in the soudanoguinea transition zone of Benin Republic. The research questions include: what is the rate at which the land cover is changing annually? What are the main and significant driving forces of the observed changes?

\section{Study Area}

The soudano-guinea transition zone of Benin covers mainly the Central part of the country. The area under this study extends between $7^{\circ} 30^{\prime}$ and $9^{\circ} 00^{\prime}$ of North latitudes and between $1^{\circ} 38^{\prime}$ and $2^{\circ} 46^{\prime}$ of East longitudes (figure 1). It is located in the transition climatic zone between the sub-equatorial or guinea and sudanian climates (Afouda, 1990). The rainfall pattern is straddling on the bimodal distribution of the South and the unique rainfall modality of the North. The total annual rainfall varies between 900 and $1200 \mathrm{~mm}$. Temperature and its monthly mean values oscillate between 24 and $32^{\circ} \mathrm{C}$. Vegetation presents various types of formations from dense forest to farmlands and fallow lands.

The study area occupies a large part of Oueme river basin as studied within the framework of the RIVERTWIN project (Keyzer et al., 2007). 


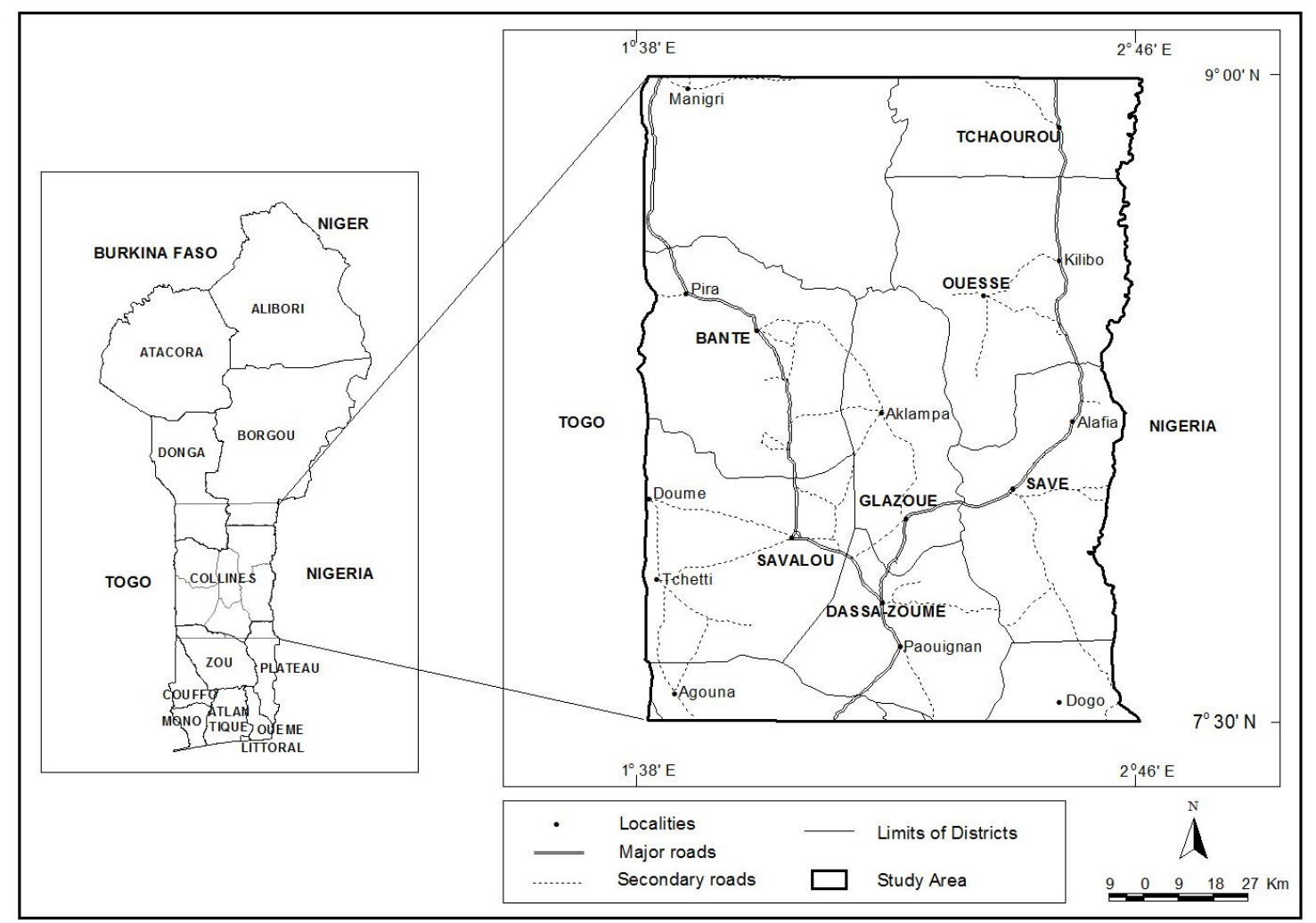

Figure 1: The Study area

\section{Research Methodology}

Data Types and Sources

Both spatial and non-spatial (socioeconomic) data were used in this study (table 1). Spatial data were collected from existing clearinghouses and mapping agencies while non-spatial data were gathered from a household survey and some national institutions. They are population data, numbers and names of villages by municipality and agricultural statistics of the central Benin between 1998 and 2010.

Table 1: Data characteristics

\begin{tabular}{lll}
\hline Data & Sources & Types \\
\hline Land cover information & Landsat TM 1986, ETM+ 2000 and OLI-TIRS & Spatial \\
& 2013, ground truthing 2013 & \\
Soil data & Soil map of Benin, sheets of Abomey and Save at & Spatial \\
& 1/200000, ORSTOM, 1975 & \\
Topographic map sheet of & Topographic maps of 'Afrique Occidentale & \multirow{2}{*}{ Spatial } \\
Save, Sokode, Zangnanado & Francaise' at 1/200000 & \\
and Abomey & & Socio-economic \\
Population data & National Censuses 2002 and 1992, INSAE & socio-economic \\
Agricultural statistics & Ministry of agriculture & socio-economic \\
Agricultural systems data & Socio-economic survey & socio-economic \\
Land use information & Socio-economic survey & \\
\hline
\end{tabular}


The household survey was carried out in 68 settlements out of 337 of the study area and the questionnaire was administered in 430 households. Municipalities whose settlements were selected for the investigations were indeed recognized as the major areas of agricultural production in Benin and as places that feature high pressure on forest resources.

\section{Research approach}

The satellite images used for the extraction of land cover information were geometrically checked and corrected through georeferencing and resampling. Their contrast was enhanced and color composites including both false color and pseudo natural color carried out.

A supervised classification using Maximum Likelihood Algorithm in ENVI 4.2 software package was performed on the images. Land cover types identified are: dense forest, light forest, woody and shrub savannah, gallery forest, water bodies, settlements, bare land and exposed rocks, farmlands and fallows. They were confirmed, assembled according to their spectral properties and the results were validated after a thorough ground truthing exercise during which at least 30 GPS (Global Positioning Systems) points in each category of land cover were checked.

The formula used for the calculation of the rate of change for each land cover type is presented as follows (Puyravaud, 2003).

$T=\left(1 /\left(t_{2}-t_{1}\right)\right) \times \ln \left(S_{2} / S_{1}\right)$

; $t$ is the number of years of evolution, $\ln$ the logarithm, $S_{1}$ and $S_{2}$ the areas of a land cover type in years $t_{1}$ and $t_{2}$.

In all the nine land cover maps sheets covering the study area (figure 2), the average rate of change of land cover types varied between -8.7 and $-1.13 \%$ (table 2).

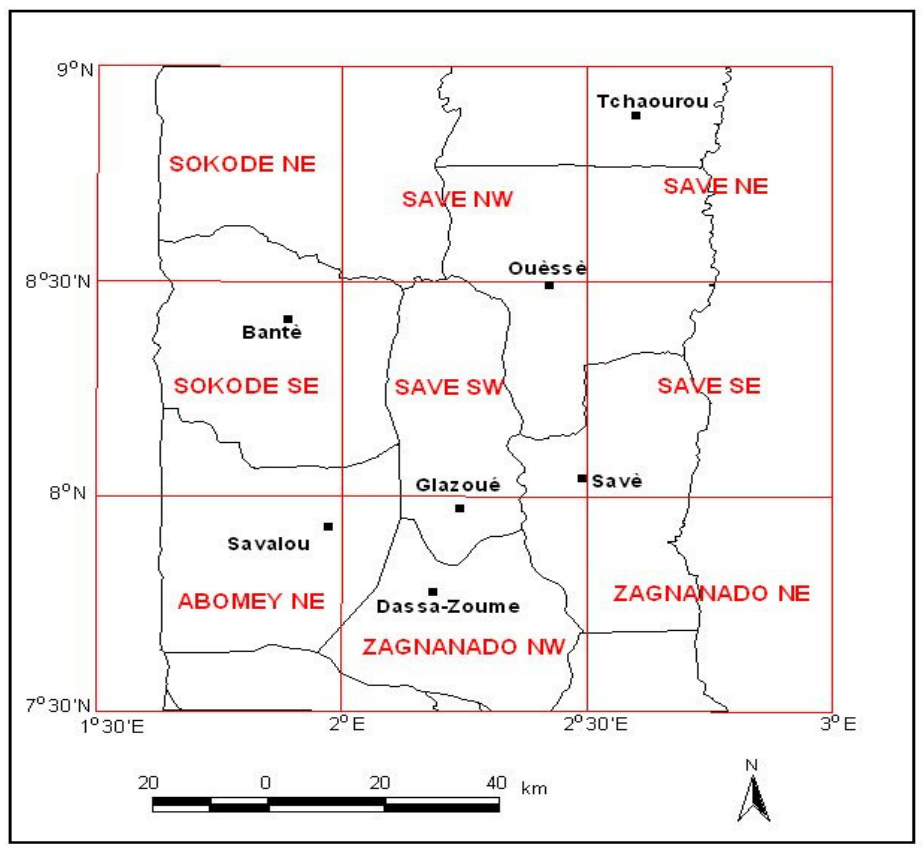

Figure 2: Gridding of the area of study in 30'by 30' sheets 
Table 2: Rates of Land cover change between 1986 and 2013

\begin{tabular}{llll}
\hline Sheets & $1986-2000$ & $2000-2013$ & Average rate of change \\
\hline Abomey NE & -2.68 & -6.9 & -4.79 \\
Save NE & -0.79 & -6.59 & -3.69 \\
Save NO & 3.14 & -9.21 & -3.035 \\
Save SE & 1.67 & -8.62 & -3.475 \\
Save SO & 5.22 & -10.62 & -2.7 \\
Sokode NE & -0.65 & -1.6 & -1.125 \\
Sokode SE & -0.17 & -8.25 & -4.21 \\
Zagnanado NE & -1.14 & -14.29 & -7.25 \\
Zagnanado NO & -0.21 & -16.4 & -8.77 \\
\hline Average & 0.49 & -9.16 & -4.34 \\
\hline
\end{tabular}

The rate was transformed into a categorical variable due to its continuous nature. Four major intervals were created and a weight ranging from 1 to 4 was given to each. The rate of land cover change was interpolated using Kriging technique in order to appreciate the spatial configuration and trend in the study area.

Logistic Multiple Regression (LMR) model is adopted to test the relationship between the rate of land cover change

$$
\hat{\mathrm{p}}=\frac{\exp \left(\mathrm{b}_{0}+\mathrm{b}_{1} \mathrm{x}_{1}+\mathrm{b}_{2} \mathrm{x}_{2}+\ldots+\mathrm{b}_{\mathrm{p}} \mathrm{x}_{\mathrm{p}}\right)}{1+\exp \left(\mathrm{b}_{0}+\mathrm{b}_{1} \mathrm{x}_{1}+\mathrm{b}_{2} \mathrm{X}_{2}+\ldots+\mathrm{b}_{\mathrm{p}} \mathrm{X}_{\mathrm{p}}\right)}
$$

Where

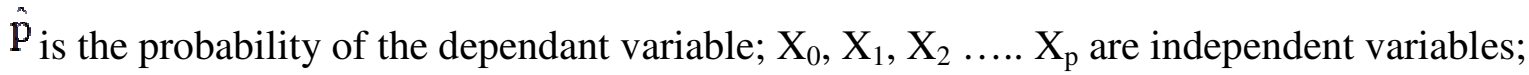
and $b_{0}$ through $b_{p}$ are the coefficients of the explanatory variables. The variables are codified and classified in three categories as they are binary, categorical or continuous (Table 2). and independent variables considered as potential factors of land cover change (Tayyebi et al., 2014; Li et al., 2013; Martinez et al., 2011; Mitsuda and Ito, 2010). It involves a mathematical relationship between a set of independent variables and a dependent condition (Guo et al., 2016; Mertens et al. 2000).

LMR is presented in various forms and can be written as follows (Braak and Looman, 1987): 
Rate of Land Cover Change and its Determinants in the Soudano-Guinea................JOSEPH OLOUKOI

Table 2 Description of variables

\begin{tabular}{lllllll}
\hline Variables & Description & $\begin{array}{l}\text { Type of } \\
\text { data }\end{array}$ & Mean & $\begin{array}{l}\text { Standard } \\
\text { deviation }\end{array}$ & Min & Max \\
\hline $\begin{array}{l}\text { Dependent } \\
\text { Variable }\end{array}$ & $\begin{array}{l}\text { Land cover change } \\
\text { rate }\end{array}$ & Categorical & -4.34 & 2.21 & -8.77 & -1.13 \\
\hline & Accessibility & Binary & 0.46 & 0.50 & 0.00 & 1.00 \\
& Land availability & Binary & 0.98 & 0.15 & 0.00 & 1.00 \\
& Access to credit & Binary & 0.12 & 0.33 & 0.00 & 1.00 \\
& Male labor force & Categorical & 1.18 & 1.34 & 0.00 & 7.00 \\
Explanatory & Female labor force & Categorical & 0.91 & 1.03 & 0.00 & 5.00 \\
Variables & $\begin{array}{l}\text { Rank of agriculture } \\
\text { in the income }\end{array}$ & Binary & 0.63 & 0.48 & 0.00 & 1.00 \\
& sources & & & & & \\
& Population Growth & Continuous & 3.69 & 0.43 & 2.87 & 5.42 \\
& Soil fertility & Categorical & 2.97 & 0.51 & 1.00 & 5.00 \\
& Distance to markets & Continuous & 31.27 & 86.38 & 0.02 & 400.00 \\
\hline
\end{tabular}

LMR model was run in STATA statistical package, version 11.

\section{Results and Discussion}

\section{Land Cover Change Process}

The dynamics in land cover pattern is characterized by the conversion of land cover types (figure 3 ). Hence, the area of each land cover type reduced or increased within the time frame of this study. Dense forests lost more than $90 \%$ of their initial area of 1986, with an annual rate of regression estimated at $17.07 \%$ from 1986 to 2000 , and almost $0.1 \%$ from 2000 to 2013. The same observation is made with gallery forest which more than $90 \%$ of its area was cleared, with an annual rate of regression estimated at $15.8 \%$ from 1986 to 2000. Meanwhile, these vegetation formations severely regressed, but they were converted into light forest, farmlands and fallow and then shrub and woody savanna, whose areas witnessed a gradual progression from 1986 to 2013.

We observed two processes: savanization and anthropogenisation. Savanisation is the transition of dense vegetation formation to light forest or shrub and woody savanna. Between 1986 and 2000, almost $35 \%$ of dense forest went through that process. Anthropogenisation process is characterized by the extension of farmland and fallows, settlements (Oloukoi, 2013; Orekan, 2007; Mama, 2002). Between 1986 and 2000, the land cover rate of almost $5 \%$ is the result of the progression observed in land cover types such as fallow and farmlands, built up areas and savanna. The same observation was made between 2000 and 2013.

From the analysis of land cover change, the annual rate of change approximates $-4.34 \%$. The rate appeared very high compared to other regions of the country. The average rate of deforestation according to Global Forest Assessment made by FAO is $-1.3 \%$ from 1990 to $2000,-1.1 \%$ from 2000 to 2010 and $-1.2 \%$ from 1990 to 2015 (FAO, 2015), confirming that the area is ahead of many other parts of the country in term of deforestation. 


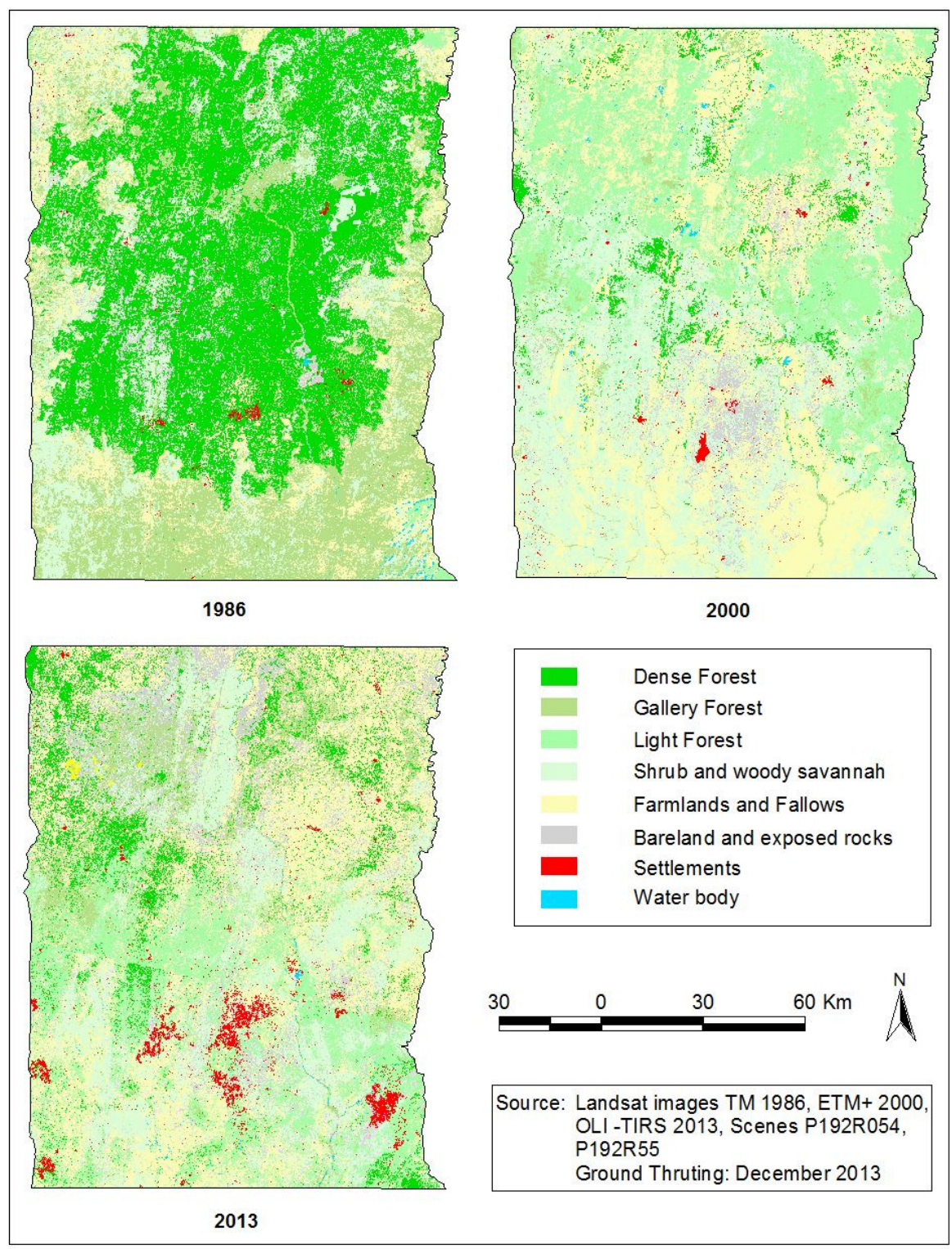

Figure 3: Land cover dynamic process

\section{Determinants of Land Cover Change Rate}

Four modalities of land cover change rates were considered in the analysis of the drivers of land cover change. The first modality extends between -4 and $-1 \%$, the second covered the rates between -7 and $-4 \%$. The third and fourth modalities correspond to the rates of change extending respectively between -8 and $7 \%$ and -9 and $-8 \%$. It is observed that the rates of land cover change increase towards the southern part of the study area (figure 4). 


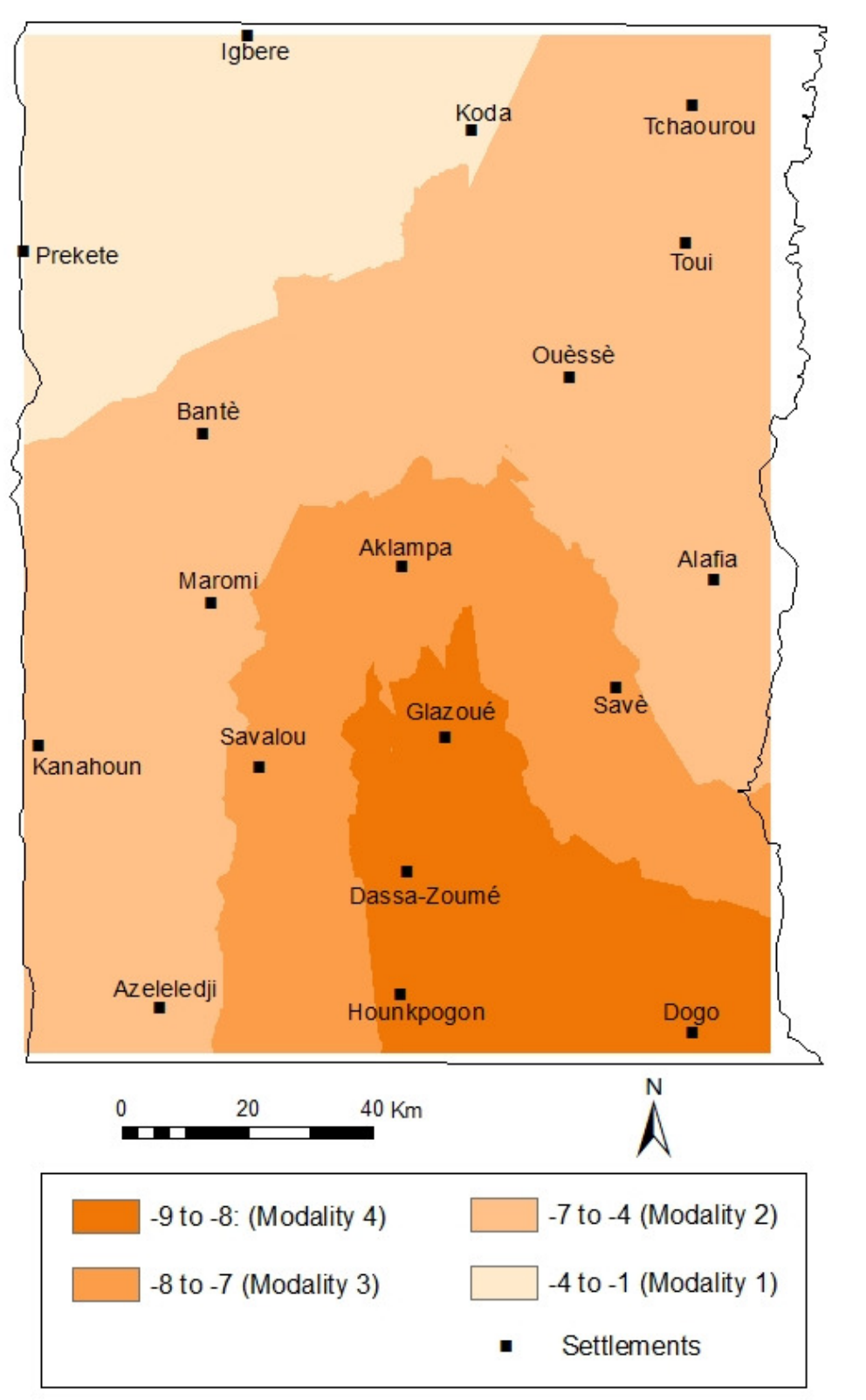

Figure 4: Spatial trend of land cover change rates in the central Benin

Logistic Multiple Regression analysis reveals that the model is significant at $1 \%$ threshold with a Chi Square $\left(\chi^{2}\right)$ estimated at 306.17. All the variables derived from the model explained about $35.30 \%\left(\mathrm{R}^{2}\right)$ the rate of land cover change (Table 3). 
Table 3: Logistic Multiple Regression (LMR) model output

\begin{tabular}{lllll}
\hline Variables & Modality 1 & Modality 2 & Modality 3 & Modality 4 \\
\hline Intercept & $-19.34(5.649)^{* * *}$ & $2.704(1.874)$ & $15.819(2.822)^{* * *}$ & $-2.378(2.769)$ \\
Accessibility of villages & $1.333(0.506)^{* * *}$ & $0.445(0.159)^{* * *}$ & $-0.495(0.210)^{* *}$ & $0.809(0.247)^{* * *}$ \\
Land availability & $-0.678(0.851)$ & $-0.249(0.278)$ & $0.143(0.360)$ & $0.160(0.450)$ \\
Access to credit & $-1.150(0.939)$ & $-0.217(0.574)$ & $-0.629(0.791)$ & $-1.438(1.153)$ \\
Rank of agriculture in the & $1.505(0.452)^{* * *}$ & $1.183(0.406)^{* * *}$ & $1.290(0.413)^{* * * *}$ & $1.333(0.414)^{* * *}$ \\
income sources & & & & \\
Population Growth & $4.646(1.174)^{* * *}$ & $-0.588(0.380)$ & $-4.837(0.748)^{* * *}$ & $0.084(0.576)$ \\
Soil fertility & $-1.561(0.550)^{* * *}$ & $-0.094(0.340)$ & $0.520(0.383)$ & $-0.433(0.413)$ \\
Distance to markets & $0.00004(0.003)$ & $-0.001(0.002)$ & $-0.061(0.022)^{* * *}$ & $0.001(0.003)$ \\
Male labor force & $0.019(0.336)$ & $0.114(0.182)$ & $0.069(0.221)$ & $0.032(0.242)$ \\
Female labor force & $-1.383(0.694)^{* *}$ & $-0.366(0.237)$ & $0.363(0.281)$ & $-0.234(0.345)$ \\
\hline Log likelihood & -280.63028 & & & \\
Pseudo R & 35.30 & & & \\
Chi square $(\chi 2)$ & $306.17(36)^{* * *}$ & & & \\
Number of observations & 318 & & & \\
\hline
\end{tabular}

( ) standard error; **, *** indicate respectively the level of significance at 5\% and 1\%

In modality 1 , land cover change is being significantly influenced by a set of four factors namely: accessibility, rank of agriculture in the source of income, population growth, soil fertility and female labour force. An increase in accessibility by 1 unit multiplies the odds of land cover rate by 1.333 in that modality. Likewise, an increase by 1 unit in the rank of agriculture and in the population growth multiplies the odds of land cover rate by 1.505 and 4.646 respectively. These variables are positive except soil fertility that connotes a negative influence on land cover in that modality. Soil fertility is inversely proportional to the rate of land cover change in that modality. This can be explained by the fact that non fertile soils are not subjected to intense agricultural activities. For years, these soils may be left as fallow lands and they can gain more cover over time.

Modality 2 reveals a set of two factors that explain significantly and positively the rate of land cover change. The factors are accessibility (0.445) and the priority given to agriculture which has the greatest positive influence (1.183). Four factors influence either negatively or positively the rate of land cover change in Modality 3. For example, accessibility, population growth and Distance to markets have shown a negative influence on land cover rate in that modality while the priority given to agricultural activities in the source of income shows a positive influence. Modality 4 is similar to modality 2 in term of factors explaining changes in land cover. The significant factors in that modality are accessibility (0.809) and rank of agriculture in the source of income (1.333). This modality displays the highest rates of change opining that the influence of factors is strong as shown in their odds values compared to modality 2 .

In all the modalities of land cover change rates, it is observed that the coefficients of variable 'rank of agriculture in the source of incomes' are positive and significant at $1 \%$. This indicates that the variable influences 
positively the changes in land cover in the study area. Hence, as the pressure from agricultural sector increases, the demand in land cover change also augments.

All the factors explained about $35.30 \%\left(\mathrm{R}^{2}\right)$ the rate of land cover change. This established that there are other factors to explore, especially indirect factors such as political, economical and technological factors. The study also revealed two preeminent factors (rank of agriculture in the source of income and village accessibility) explaining significantly the rate of land cover change.

The pre-eminence of agricultural activity in the study area is confirmed by the extension of farmlands (Badjana et al., 2015; Do et al., 2014). Agriculture is mainly characterized by shifting cultivation associated with bushfire (Thamm, 2008). The average area cultivated per year varies between 0 and 5.33 ha. Majority of farmers (more than $65 \%$ ) cultivate between 0 and 1 ha, which confirmed the presence of small scale farmers. Approximately $33 \%$ of farmers cultivate between 1 and 5 ha. Only $2 \%$ cultivate more than 5 ha. The two major crops dominating the use of land are cotton and yam. They are associated with other yields such as maize, cassava, groundnuts etc. Cotton crop represents about $13 \%$ of the Gross Domestic Product (GDP) and $80 \%$ of the agricultural exports which constitute a vital resource for Beninese economy (Wennink et al., 2013). Yam requires a very rich soil for its growth. Firstly, the land must be new or a long fallow which facilitates an important accumulation of organic matter for a good reconstitution of soil (Floquet et al., 2012). Secondly, it needs a sufficient quantity of water. Farmers are forced to clear new spaces.

Accessibility is a factor that positively influences land cover change. It is considered as the ease with which individuals can reach a place from other locations, using a means of transportation. It depends, on the respective geographical positions of places of origin, the destination and the level of service offered by the modes of transportation (Lee, 1979). In line with this, we considered seasonal practicability of roads from the production spots to the settlements (Muller and Zeller, 2002) and from settlements to markets (Aguiar et al., 2007; Mertens et al., 2002). About 50\% of the actors considered the roads to their settlements as good enough to facilitate accessibility to their localities. Producers depend on three specific locations: their residence, represented by the settlement, the production spots (farms, forests exploitation or charcoal production locations) and the places of exchange or distribution of their products (markets). In modality 3 , it is observed that a decrease by a unit of distance to market increased the odds of land cover change rate by 0.06 unit. If the conditions of transportation are optimal (good roads, good transportation means, short distances to markets etc.), producers are encouraged to produce more. Thus more pressure is deployed on land resources.

\section{Conclusion}

Land cover change assessment confirmed a reduction in dense vegetation formations while other land cover types such as farmlands and savannah witness an expansion within the timeframe of the study. Savanisation and 
anthropogenisation processes observed are expressed by an annual rate of land cover change estimated at an average lost of $-4.34 \%$ annually. This rate appears to be much higher than the national rate of $1.2 \%$ estimated by FAO in 2015 . This indicated that the soudano-guinea transition zone is one of the areas where pressure on vegetation cover is very high in Benin Republic. It is observed that agriculture and accessibility are significantly influencing land cover change in all the four modalities retained. Many of these factors are direct or proximate cause of land cover change. There is still a need to dwell more on indirect factors which remotely influence environmental dynamics. To achieve that, macro and micro economic decisions, infrastructural policies, cultural context and land management policy should be taken into account in future studies.

\section{Acknowledgement}

The author acknowledges the help provided by Dr Laurent Oloukoi in the use of STATA statistical package.

\section{References}

Afouda, F. (1990). L'eau et les cultures dans le Bénin central et septentrional: étude de la variabilité des bilans de l'eau dans leurs relations avec le milieu rural de la savane africaine. Thèse de doctorat nouveau régime. Paris IV Sorbonne, $428 \mathrm{p}$.

Aguiar, A.P.D., Camara, G., Isabel, M. and Escada, S. (2007). Spatial statistical analysis of land-use determinants in the Brazilian Amazonia: Exploring intra-regional heterogeneity, Ecological Modelling, 209: 169-188
Badjana, H.M., Helmschrot, J., Selsam, P., Wala, K., Flügel, W-A., Afouda, A. and Akpagana, K. (2015). Land cover changes assessment using object-based image analysis in the Binah River watershed (Togo and Benin). Earth and Space Science, 2: 403-416.

Bian, L. and West, E. (1997). GIS modelling of elk calving habitat in a prairie environment with statistics. Photogramm. Eng. Remote Sens. 63: 161-167.

Braak, C.J.F. and Looman, C.W.N. (1987). Regression, Data Analysis in Community and Landscape Ecology (R.H. Jongman, C.J.F. Braak, and O.F.R. van Tongeren, editors), Pudoc, Wageningen, Netherlands, pp. 29-77.

Do, T., Bigot, S. and Galle, S. (2014). Vegetation Activity in the Upper Oueme Basin (Benin, Africa) studied from SPOT-VGT (20022012) according to Land Cover. International Journal of Remote Sensing Applications, 4(3): 121133.

European Research Area. (2004). Integrated Watershed Management. RIVERTWIN a regional model for integrated water management in twinned river basins. European Commission, 1-2 $\mathrm{p}$

FAO (2015). Global Forest Resources Assessment 2015. Desk reference. Rome, $253 \mathrm{p}$.

Floquet, A.B., Maliki, R., Tossou, R.C. and Tokpa, C. (2012). Évolution des systèmes de production de l'igname dans la zone soudanoguinéenne du Bénin. Cahiers Agricultures, 21: 427-437. 
Guo, F., Su, Z., Wang, G., Sun, L., Lin, F., Aiqin, Liu, A. (2016). Wildfire ignition in the forests of southeast China: Identifying drivers and spatial distribution to predict wildfire likelihood. Applied Geography, 66: 12-21

Hibbarda, K., Janetos, A., van Vuuren, D. P., Pongratz, J., Rose, S.K., Betts, R., Herold, M. and Feddema, J.J. (2010). Research priorities in land use and land-cover change for the Earth system and integrated assessment modelling. International Journal of Climatology, 30(13): 2118-2128.

Hu, G.Y., Dong, Z., Lu, J. and Yan, C. (2012). Driving forces of land use and land cover change (LUCC) in the Zoige Wetland, Qinghai Tibetan Plateau. Sciences in Cold and Arid Regions, 4(5): 422-430.

Igue, A.M., Houndagba, C.J., Gaiser, T., and Stahr, K. (2012). Accuracy of the Land Use / Cover classification in the Oueme Basin of Benin (West Africa). International Journal of AgriScience, 2(2): 174-184.

IMPETUS West Africa (2003). An Integrated Approach to the Efficient Management of Scarce Water Resources in West Africa: Case studies for selected river catchments in different climatic zones, Final Report, An interdisciplinary project of the Universities of Cologne and Bonn, 156p.

Kanianska, R., Kizekova, M., Novacek, J. and Zeman, M. (2014). Landuse and land-cover changes in rural areas during different political systems: a case study of Slovakia from 1782 to 2006. Land Use Policy, 36: 554-566.
Karanam, H., Nadipena, A.R., Velaga, V.R., Gummapu, J. and Edara, A. (2013). Land use/land cover patterns in and around Kolleru lake, Andhra Pradesh, India using remote sensing and GIS techniques. International Journal of Remote Sensing \& Geoscience (IJRSG), 2(2): 1-7.

Keyzer, M.A., Sonneveld, B.G.J.S. and Pande, S. (2007). The impact of climate change on crop production and health in West Africa: an assessment for the Oueme River Basin in Benin, Centre for World Food Studies, 106 p.

Lawrence, P.J. and Chase, T.N. (2010). Investigating the climate impacts of global land cover change in the community climate system model. International Journal of Climatology, 30(13): 2066-2087.

Lee, L. (1979). Factors Affecting Land Use Change at the Urban-Rural Fringe. Iowa Agriculture and Home Economics Experiment Station, Ames, Iowa, project number 2045. Growth and Change, 9580, 25-31.

Li, X., Zhou, W. and Ouyang, Z. (2013). Forty years of urban expansion in Beijing: What is the relative importance of physical, socioeconomic and neighborhood factors? Applied Geography, 38: 110.

Mama, V.J. (2002). An integrated approach for land-use/cover change analysis in a central region of Benin Republic. PhD Thesis, Geography, University of Lagos, Lagos, 221 p.

Martinez, J.A., Suarez-seoane, S. and Calabuig, E.L. (2011). Modelling the risk of land cover change from environmental and socio-economic 
drivers in heterogeneous and changing landscapes: The role of uncertainty. Landscape and Urban Planning, 101(2): 108-119.

Melillo, J., Field, C. and Moldan, B., (2003). Interactions of the major biogeochemical cycles, Island Press, Washington, DC.

Mertens, B. and Lambin, E.F. (2000). Land-cover change trajectories in southern Cameroon, Annals of the Association of American Geographers, 90(3): 467-494.

Mertens, B., Poccard-Chapuis, R., Piketty, M.G., Lacques, A.E. and Venturieri, A. (2002). Crossing spatial analyses and livestock economics to understand deforestation processes in the Brazilian Amazon: the case of Sao Felix do Xingu in South Para. Agric Econ, 27: 269-294.

Mitsuda, Y. and Ito, S. (2010). A review of spatial-explicit factors determining spatial distribution of land use/land-use change. Landscape Ecol Eng, 7: 117-125.

Muller, D. and Zeller, M. (2002). Land use dynamics in the central highlands of Vietnam: a spatial model combining village survey data with satellite imagery interpretation. Agric Econ, 27: 333354.

Oloukoi, J. (2013). Scénario socioéconomique et écologique des changements de l'occupation des terres au Bénin. VertigO - la revue électronique en sciences de l'environnement, 13(1): 1-22; DOI:10.4000/vertigo.13267.

Oloukoi, J., Mama, V.J. and Agbo, F.B. (2007). Modélisation de la dynamique de l'occupation des terres dans le Département des Collines au Bénin. Télédétection, 6(4): 305-323.

Orekan, V. (2007). Implementation of the local land-use and land-cover change model CLUE-s for Central Benin by using socio-economic and remote sensing data. $\mathrm{PhD}$ Thesis, University of Bonn, 204 p.

Puyravaud, J.P. (2003). Standardizing the calculation of the annual rate of deforestation. Forest Ecology and Management, 177(1-3): 593-596.

Showqi, I., Rashid, I. and Romshoo, S. A. (2014). Land use land cover dynamics as a function of changing demography and hydrology. GeoJournal, 79(3): 297-307.

Takahashi, H.G., Yoshikane, T., Hara, M., Takata, K. and Yasunari, T. (2010). High-resolution modelling of the potential impact of landsurface conditions on regional climate over Indochina associated with the diurnal precipitation cycle. International Journal of Climatology, 30(13): 2004-2020

Thamm, H-P. (2008). Les feux de brousse au Bénin. In: M. Judex, and H.-P. Thamm, (eds) IMPETUS Atlas Benin. Research Results 2000 - 2007 (pp.97-98). Department of Geography, University of Bonn, Germany.

Thamm, H.-P., Judex, M. and Menz, G. (2005). Assessing and Modelling Land Use Land Cover Changes in Benin, Zeitschrift für Photogrametrie und Fernerkundung, 3: 191-199.

Tayyebi, A., Pijanowski, B.C., Linderman, $\mathrm{M}$. and Gratton, C. (2014). Comparing three global parametric and local non-parametric 
Rate of Land Cover Change and its Determinants in the Soudano-Guinea................JOSEPH OLOUKOI

models to simulate land use change in diverse areas of the world. Environmental Modelling \& Software, 59: 202-221.

Wennink, B., Meenink, J.W. and Djihoun, M. (eds). (2013). La filière coton tisse sa toile au Bénin. Les organisations de producteurs étoffent leurs services aux exploitations agricoles familiales.
Cotonou/Amsterdam, $\quad$ KIT Publishers, 112p.

Were, K., Dick, Ø.B. and Singh, B.R. (2014). Exploring the geophysical and socio-economic determinants of land cover changes in Eastern Mau forest reserve and Lake Nakuru drainage basin, Kenya. Geojournal, 79(6): 775-790. 